\title{
Psychometric Properties of Brief Sensation Seeking Scale (BSSS-4) in a Sample of Turkish Adolescents
}

\author{
Eyüp ÇELİK*
}

\begin{abstract}
The purpose of the current research was to investigate the psychometric properties of the BSSS-4 in Turkish sample. In this study, firstly, the relationship between Turkish and English version was examined by Pearson Product-Moment Correlation for the linguistic equivalence. Exploratory factor analysis showed that four items loaded on single-factors as the factor structure of the original scale. The present study found that the Cronbach's Alpha coefficient of the scale is .81. These results demonstrated that the Turkish form of the Brief Sensation Seeking Scale for Adolescents is a valid and reliable instrument.
\end{abstract}

Keywords: Sensation seeking, adolescent, validity, reliability, scale adaptation.

\section{Ergenler için Kısa Heyecan Arayışı Ölçeği'nin Psikometrik Özelliklerinin İncelenmesi}

\begin{abstract}
Öz
Bu araştırmanın amacı, Kısa Heyecan Arayışı Ölçeği'nin Türkçe versiyonunun psikometrik özelliklerinin incelenmesidir. Ölçeğin uyarlama çalışmasında öncelikle dilsel eşdeğerliğine bakılmıştır. Ölçeğin yapı geçerliği açımlayıcı faktör analizi ile incelenmiştir. Güvenirliği için ise iç tutarlılık katsayısı hesaplanmıştır. Yapılan açımlayıcı faktör analizi sonucu ölçeğin Türkçe versiyonunun orijinal yapısına uygun 4 maddeli tek faktörlü bir yapıya sahip olduğu ve güvenirlik analizinde iç tutarlılık katsayısının .81 olduğu görülmüştür. Madde analizi sonucu, ölçeğin maddelerine ilişkin düzeltilmiş madde-toplam korelasyonlarının .56 ile .68 arasında değiştiği bulunmuştur. Bu sonuçlara göre Ergenler için Kısa Heyecan Arayışı Ölçeğinin Türkçe versiyonunun geçerli ve güvenilir bir ölçme aracı olduğu söylenebilir.
\end{abstract}

Anahtar Kelimeler: Heyecan arayışı, ergen, geçerlik, güvenirlik.

* Dr. Sakarya University Faculty of Education Educational Sciences, eyupcpdr@hotmail.com, eyupcelik@sakarya.edu.tr, Sakarya/Turkey. 


\section{INTRODUCTION}

Adolescence period generally characterize with growth in problem behaviors like risk taking (Arnett, 1999; Buchanan \& Holmbeck, 1998) and beginning of substance use (Donohew, Hoyle, Clayton, Skinner, Colon, \& Rice, 1999). Byck, Swann, Schalet, Bolland, \& Mustanski (2014) stated that adolescent' sensation seeking is an important determiner these problem behaviors. Sensation seeking level increases with age from childhood to adolescence (Stephenson, Hoyle, Palmgreen, \& Slater, 2003), after which it begin to decrease after late adolescence years (Steinberg, 2008). This fall and rise in the sensation seeking level may be caused by biological, psychological, and social development. Because sensation seeking expresses as a need for biological, and physiological arousal (Bardo, Donohew, \& Harrington, 1996). According to Zuckerman (1979), sensation seeking is biosocial personality tendency, it was also characterized by the inclination toward take social and physical risks (cited in Manna, Faraci, \& Como, 2013). In this context, we can say that sensation seeking is influenced by genetic, biological, psychological and social factors.

People with high sensation seeking may experience dangerous activities like criminal activity (MacPherson, Magidson, Reynolds, Kahler, \& Lejuez, 2010), and substance use (Donohew et al., 1999). Previous studies demonstrated that sensation seeking was relate to risk taking, illegal and/or risky behaviors (MacPherson et al., 2010), sexual risk-taking (Donohew Zimmerman, Cupp, Novak, Colon, \& Abell, 2000; Hoyle, Fejfar, \& Miller, 2000), dangerous sports (Diehm \& Armatas, 2004; Hansen \& Breivik, 2001), alcohol use (Cicognani \& Zani, 2011; MacPherson et al., 2010), substance use (Kopstein, Crum, Celentano, \& Martin, 2001), and reckless driving (Curran, Fuertes, Alfonso, \& Hennessy, 2010). Furthermore, higher sensation seeking is relate to lower school belongings and quality of home life (Stephenson et al., 2003).

Due to high sensation seeking, the spread of substance use, violent behavior, sexual risktaking among adolescents may negatively affect their healty development, peer relationship, academic achievement and career development, they also negatively affect other individuals' live in the community due to results of risky behaviors. Thus, for both adolescents' healthy development and community mental health, the studies must be done to investigate factors, increasing and decreasing adolescent'sensation seeking level in order to determine risky behaviours. Because there is no a scale for measuring this concept, the studies about sensation seeking and other related variables can't be made. For doing studies in this topic, a validity and reliability scale is needed in our community. Examining the literature, although there are many studies that the psicometric properties of the BSSS-4 was examined in different cultures (e.g., Hoyle, Stephenson, Palmgreen, Lorch, \& Donohew, 2002; Stephenson et al. 2003; Vallone, Allen, Clayton, $\&$ Xiao, 2007), it is seen that there is no scale to measure sensation seeking level for child, adolescent, and adult in Turkey, and there is no research examined the validity and reliability of the BSSS- 4 in the Turkish sample. Thus, the purpose of the current study was to adapt the BSSS-4 into Turkish.

\section{METHOD}

\subsection{Participants}

The sample of this study consist of 350 eightgrade students who participated in the study voluntarily. 169 of them were males. The perceived socio-economic status was $46 \%$ high-level income, 5\% lower level income, and 49\% midlevel income. The perceived academic achievement level was $31 \%$ high-level academic 
achievement, 3\% lower level academic achievement, and $66 \%$ mid-level academic achievement.

\section{2. Research Instrument}

Brief sensation seeking scale (BSSS-4). Stephenson et al. (2003) investigated psychometric properties of BSSS-4. They found that BSSS-4 was one factor scale including four questions; the coefficient alpha was .66; and the average corrected item-total correlation was .44. The scale was anchored by strongly disagree and strongly agree. The items of the scale are illustrated Table 2. The scale does not include any reversed item. Scores are calculated by summing the responses to the items, higher scores are indicative of higher levels of BSSS-4.

\subsection{Procedure}

The translation process of the BSSS-4, firstly scale items were translated in Turkish, and then back-translation in English was made to determine their consistencey by researcher and 2 expert translators. The Turkish form was then re-examined by two Turkish teachers, who work in the secondary schools, in order to look at the meaning and grammar, and thereafter, the Turkish form was administered 37 adoles- cents to check identify unclear items. After that, to examine linguistic equivalence, Turkish and English version of the scale were administered 34 adolescent, selected by teacher according to students' academic achievement in the English course. Furthermore, the scale was applied to 40 individuals for test-retest reliability.

In the present study, the linguistic equivalence of the scales' Turkish and English version was examined using Pearson Product-Moment Correlation. To examine factor structure, explanatory factor analysis (EFA) was used. For determine the reliability of the scale, Cronbach's Alpha formula was used. Furthermore, for item analysis, t-test, and corrected item-total correlations were used.

\section{FINDINGS}

\subsection{Linguistic Equivalence}

In the present research, to examine linguistic equivalence, Turkish and English version of the BSSS-4 were administered 34 adolescent. Thereafter, to investigate the association among Turkish and English version of the BSSS-4, Pearson Product-Moment Correlation was used. Findings are illustrated in Table 1.

Table 1. The Linguistic Equivalence of the BSSS-4

\begin{tabular}{|c|c|c|c|c|}
\hline Items & Application & Mean & $S D$ & $r$ \\
\hline \multirow{2}{*}{1} & English form & 2,47 & 1,21 & \multirow{2}{*}{$.75^{* *}$} \\
\hline & Turkish form & 2,14 & 1,18 & \\
\hline \multirow{2}{*}{2} & English form & 2,17 & 1,16 & \multirow{2}{*}{$.78^{* *}$} \\
\hline & Turkish form & 2,00 & 1,12 & \\
\hline \multirow{2}{*}{3} & English form & 2,00 & 1,10 & \multirow{2}{*}{$.64^{* *}$} \\
\hline & Turkish form & 1,64 & 0,94 & \\
\hline \multirow{2}{*}{4} & English form & 1,88 & 1,20 & \multirow{2}{*}{$.88^{* *}$} \\
\hline & Turkish form & 1,70 & 1,08 & \\
\hline
\end{tabular}

${ }^{* *} p<0.001,{ }^{*} p<0.05$

According to the result of correlation analysis, items' correlation coefficients between the Turkish and English version of the BSSS-4 ranged from 0.64 to to 0.88 .

\subsection{Structure Validity}

The factor structure of the BSSS-4 was examined with EFA. In this analysis, the KMO coefficient was .75; the Barlett Sphericity test $\chi 2$ value was $523,376(p<0.001)$. According to 
Buhner (2006), KMO-values above 0.60 indicate an acceptable level of compatibility of the variables with the scale (cited in Fekete, 2009). Furthermore, to determine the limit of the factor number, the scree plot was examined. The scree plot is illustrated in Figure 1.
These findings show that the scale's items are factorable and the sample of the present study is suitable and enough. The results of the EFA are illustrated in Table 2.

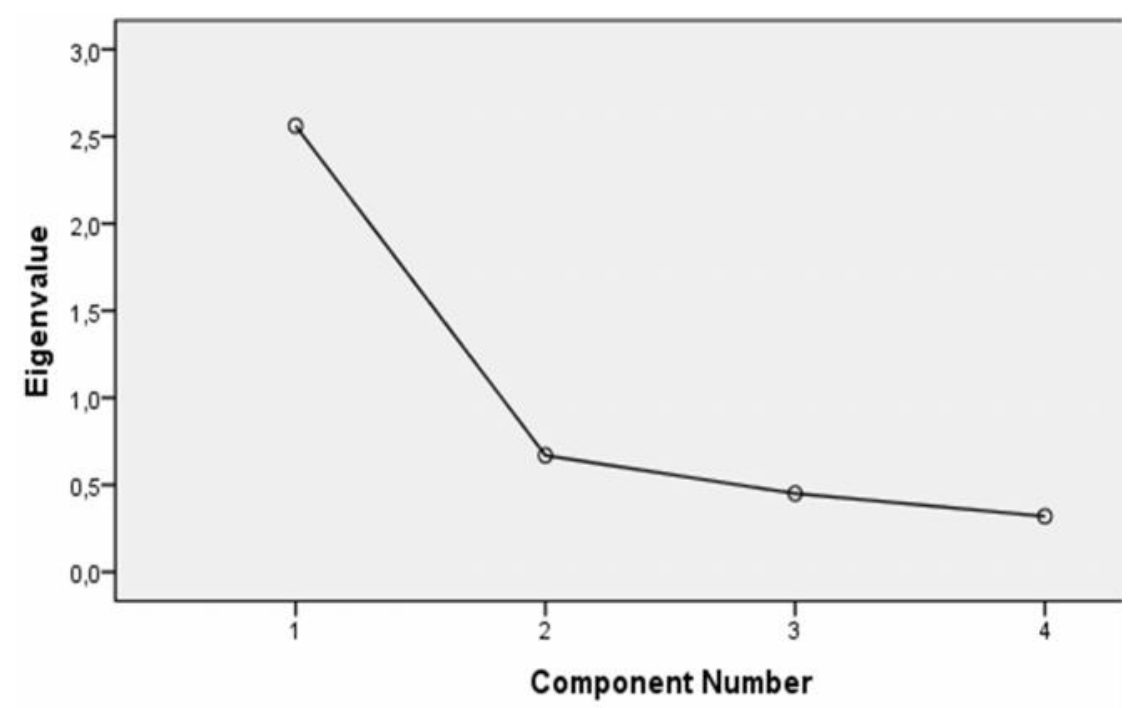

Figure 1. Scree Plot

Table 2. The Result of the Exploratory Factor Analysis

\begin{tabular}{llc}
\hline Items & Factor Loadings & Extraction \\
\hline 1. I would like to explore strange places. & .82 & .67 \\
2. I like to do frightening things. & .84 & .71 \\
3. I like new and exciting experiences, even if & .80 & .63 \\
$\quad$ I have to break the rules. & & .55 \\
4. I prefer friends who are exciting and un- & .74 & 2,56 \\
$\quad$ predictable. & & 64.02 \\
\hline Eigenvalue & & \\
Total Variance $(\%)$ &
\end{tabular}

The first analysis in this research revealed one factor that explained $64.02 \%$ of the total variance with a factor eigenvalue of over 2.56 . Furthermore, factor loading of the BSSS-4 ranged between 0.74 and 0.84 .

\subsection{Reliability}

Cronbach's Alpha formula and test-retest reliability were used to determine the reliability level of the scale. Scale's internal consistence coefficient was found .81 and was statistically significant at the $p<0.01$ level. According to Hair, Black, Babin, \& Anderson (2010), Cronbach's alpha may decrease to .60 in the studies. In this context, this instrument has excellent reliability level. Furthermore, testretest reliability examined the reliability of the 
scale. The result of the test-retest was found .84 . According to Peirce (1995), a scales' test-retest level have to be .80 or above in adaptation studies (cited in Çözüm \& Aksayan, 2003).
According to the result of the test-retes reliability analysis, we can say that the BSSS-4 has acceptable reliability level. The result of the test-retest is demonstrated in Table 3.

Table 3. The Result of the Test-retest

\begin{tabular}{lllll}
\hline Scale & Application & Mean & $S D$ & $r$ \\
\hline \multirow{2}{*}{ Brief Sensation Seeking } & First application & 7.80 & 3.61 & \multirow{2}{*}{$.84^{* *}$} \\
\cline { 2 - 5 } & Second application & 7.62 & 3.43 & \\
\hline
\end{tabular}

${ }^{* *} p<0.01$

\subsection{Item Analysis}

Corrected item-total correlations and t-test values, performing between items' means of upper $27 \%$ and lower $27 \%$ of the group points, were used for item analysis. The result of the item analysis demonstrated that corrected item- total correlations were ranged from 0.56 to 0.68 ; and $t(d f=202)$ values were ranged from 20.24 $(p<.001)$ to $25.66(p<.001)$. The results of the item analysis were statistically significant at the $p<0.001$ level. The findings concerning the item analysis are shown in Table 4.

Table 4. The Result of the Item Analysis

\begin{tabular}{lll}
\hline Items & $r_{j x}$ & $\mathrm{t}$-test \\
\hline 1 & .65 & $25.13^{* * *}$ \\
2 & .68 & $25.66^{* * *}$ \\
3 & .63 & $23.12^{* * *}$ \\
4 & .56 & $20.24^{* * *}$ \\
\hline$* * * p<.001$ & &
\end{tabular}

\section{DISCUSSION AND RESULTS}

BSSS-4, using to explore the sensation seeking of adolescents, was adapted into Turkish in the current study. Exploratory factor analysis was used to examine structure validity, it showed that the Turkish form of BSSS-4 explained $64,02 \%$ of total variance, it also demonstrated that BSSS-4 has a one factor structure as to be original. For determining the reliability of the scale, Cronbach's Alpha formula and test-retest were used. Furthermore, for item analysis, ttest, and corrected item-total correlations were used. When the result of the reliability analysis compared with the previous studies (e.g., Stephenson et al. 2003), the result of the current study demonstrated higher reliability level and corrected item-total correlations.

According to Hair, Black, Babin, \& Anderson (2010), Cronbach's alpha may decrease to .60 in the studies. In this context, instrument has excellent reliability level. Furthermore, for item analysis, t-test, and corrected item-total correlations were used. In the present study, reliability analysis showed that Chronbach Alpha and the result of the test-retest were found meaningful and high, and this result showed that the Turkish form of the scale is reliable.

According to the findings of the present study, we can say that Turkish version of the BSSS-4 can be used as valid and reliable. However, there were some limitations in the adaptation study of the BSSS-4. First, the age ranges of samples were severely restricted. Because research data were collected from the 13-15 yearold adolescents, but adolescents comprise the 10-19 year-old age group. Second, the sample groups are only of adolescents residing in a single geographic region. Thus, further studies should examine the scale' psychometric properties in different sample, selected from diverse cultural and educational backgrounds. 
On the other hand, the present study is an important first step in measuring sensation seeking among adolescents in Turkey. Furthermore, further researches should explore the BSSS- 4 in relation to other concepts, such as risk perceptions, outcome expectancies, attitudes, or descriptive norms to analyze their contribution to health behavior change in more detail.

\section{References}

Arnett, J. J. (1999). Adolescent storm and stress, reconsidered. American Psychologist, 54, 317-326.

Bardo, M. T., Donohew, R. L., \& Harrington, N. G., (1996). Psychobiology of novelty seeking and drug seeking behavior. Behavioural Brain Research, 77, 23-43.

Büyüköztürk, Ş. (2010). Sosyal bilimler için veri analizi el kitabı (12. Baskı). Ankara: PegemA Akademi Yayınevi.

Byck, G. R., Swann, G., Schalet, B., Bolland, J., \& Mustanski, B. (2014). Sensation Seeking Predicting Growth in Adolescent Problem Behaviors. Child Psychiatry \& Human Development, 46 (3), 466-473.

Cicognani, E., \& Zani, B. (2011). Alcohol use among Italian university students: The role of sensation seeking, peer group norms and self-efficacy. Journal of Alcohol and Drug Education, 55 (2), 17-36.

Curran, M. F., Fuertes, J. N., Alfonso, V. C., \& Hennessy, J. J. (2010). The association of sensation seeking and impulsivity to driving while under the influence of alcohol. Journal of Addictions $\mathcal{E}$ Offender Counseling, 30, 84-98. doi:10.1002/j.2161-1874.2010.tb00059.x

Çözüm, S., \& Aksayan, S., (2003). Kültürlerarası ölçek uyarlaması için rehber II: Psikometrik özellikler ve kültürlerarası karşılaştırma. Hemşirelikte Araştırma Geliştirme Dergisi, 1, 3-14.

Diehm, R., \& Armatas, C. (2004). Surfing: an avenue for socially acceptable risk-taking, satisfying needs for sensation seeking and experience seeking. Personality and Individual Differences, 36, 663-677.

Donohew, R. L., Hoyle, R. H., Clayton, R. R., Skinner, W. F., Colon, S. E., \& Rice, R. E. (1999). Sensation seeking and drug use by adolescents and their friends: models for marijuana and alcohol. Journal of studies on alcohol, 60 (5), 622-631.

Donohew, L., Zimmerman, R. S., Cupp, P. S., Novak, S., Colon, S., \& Abell, R. (2000). Sensation seeking, impulsive decision-making, and risky sex: implications for risk-taking and design of interventions. Personality and Individual Differences, 28, 1079-1091.

Fekete, A. (2009). Validation of a social vulnerability index in context to river-floods in Germany. Natural Hazards and Earth System Science, 9 (2), 393-403.

Hair, J., Black, W. C., Babin, B. J., \& Anderson, R. E. (2010). Multivariate data analysis (7th ed.). Upper saddle River, New Jersey: Pearson Education International.

Hansen, E. B. \& Breivik, G. (2001). Sensation seeking as a predictor of positive and negative risk behaviour among adolescents. Personality and Individual Differences, 30, 627-640.

Hoyle, R. H., Fejfar, M. C., \& Miller, J. D., (2000). Personality and sexual risk-taking: A quantitative review. Journal of Personality, 68, 1203-1231.

Hoyle, R. H., Stephenson, M. T., Palmgreen, P., Lorch, E. P., \& Donohew, R. L., (2002). Reliability and validity of a brief measure of sensation seeking. Pers. Indiv. Differences 32, 401-414.

Kopstein, A. N., Crum, R. M., Celentano, D., \& Martin, S. S. (2001). Sensation seeking needs among 8th and 11th graders: Characteristics associated with cigarette and marijuana use. Drug and Alcohol Dependence, 62, 195-203. doi:10.1016/S0376-8716(00)00170-8 
MacPherson, L., Magidson, J. F., Reynolds, E. K., Kahler, C. W., \& Lejuez, C. W. (2010). Changes in sensation seeking and risk-taking propensity predict increases in alcohol use among early adolescents. Alcoholism, Clinical and Experimental Research, 34 (8), 1400-1408.

Manna, G., Faraci, P., \& Como, M. R. (2013). Factorial Structure and Psychometric Properties of the Sensation Seeking Scale - Form V (SSS-V) in a Sample of Italian Adolescents. Europe's Journal of Psychology, 9(2), 276-288. doi:10.5964/ejop.v9i2.500

Spahi, B. Yurtkoru, E. S., \& Çinko, M. (2008). Sosyal bilimlerde SPSS'le veri analizi. İstanbul: Beta Basım Yayım Dağıtım.

Steinberg, L. (2008). A social neuroscience perspective on adolescent risk-taking. Developmental review, 28 (1), 78-106.

Stephenson, M. T., Hoyle, R. H., Palmgreen, P., \& Slater, M. D. (2003). Brief measures of sensation seeking for screening and large-scale surveys. Drug and Alcohol Dependence, 72 (3), 279-286.

Vallone, D., Allen, J. A., Clayton, R. R., \& Xiao, H. (2007). How reliable and valid is the Brief Sensation Seeking Scale (BSSS-4) for youth of various racial/ethnic groups? Addiction, 102 (2), 71-78. doi: 10.1111/j.1360-0443.2007.01957.x 


\section{Geniş Özet}

Ergenlik dönemi, meydana gelen değişimler ve yaşanan sorunlardan dolayı sigara, alkol ve uyuşturucu gibi bağımlılık yapan ve insan sağlığını ciddi boyutta etkileyen maddelerin kullanılmaya başlandığı önemli bir gelişim dönemidir. Bireyler bu dönemde yaşanan sorunlardan kaçma, farklı görünme ya da sıkıntıları bastırma çabası nedeniyle zaman zaman heyecan arayışı içine girebilirler. Ama bu kapsamda yapılan bazı davranışlar (örn. dikkatsiz araba ya da motor kullanımı), kazalara ve geçirilen deneyimler (alkol, sigara ya da uyuşturucuya başlamaya sebep olan ortamlarda bulunma) üzücü ve geri dönüşü olmayan alışkanlık ve pişmanlıklara sebep olabilir.

Heyecan arayışı içinde olan bireyler, dikkatsiz davranışlar, korunmasız cinsel ilişki, yasadışı ilaç kullanımı, basit suç aktiviteleri, dikkatsiz araç kullanma gibi davranışlara girişme eğiliminde olabilirler. Bu tür aktiviteler kritik bir gelişim dönemi olan ergenlik döneminde bireylerin hem sağlıklı gelişimlerini olumsuz etkileyebilir hem de çeşitli sağlık sorunlarına sebep olabilir. Ayrıca, bu gelişim döneminde cinsel gelişimin diğer gelişim alanlarından daha fazla ön plana çıkması ergenlerin heyecan arayışı nedeniyle korunmasız cinsel ilişki deneyimleri yaşamalarına, istenmeyen erken dönem hamileliklere ya da cinsel yolla bulaşan hastalıklara sebep olmaktadır. Ayrıca heyecan arayışı ergenlik dönemindeki öğrencilerin eğitim-öğretim sürecini ve okul başarısını etkiyebilir ve okul ortamında davranışsal sorunların ortaya çıkmasına sebep olabilir. Çünkü heyecan arayışı içinde olan bir öğrenci risk almaktan hoşlanacağı için, arkadaşlarına zarar verici davranışlarda bulunabilir, öğretmenlerine yönelik karşıt davranışlar geliştirebilir ve okuldan kaçma girişimlerinde bulunabilir. Bu yüzden, önemli bir gelişim döneminde olan ergenlerin ruhsal ve fiziksel sağlıklarının korunabilmesi için heyecan arayışı değişkenine araştırmalarda yer verilmesi gerekmektedir. Türkiye dışındaki ülkelerde ergenler üzerinde yapılan araştırmalar incelendiğinde ergenlerde heyecan arayışı değişkeninin sebep olabileceği çok sayıda sorunla ilgili araştırmaların oldu görülmektedir. Türkiye'de ise bu ve benzeri değişkenlerin ölçülmesine yönelik ölçme araçlarının olmaması nedeniyle çalışmaların yapılamadığı görülmektedir. Bu nedenle bu araştırmada Kısa Heyecan Arayışı Ölçeğinin Türkçe versiyonunun psikometrik özelliklerinin incelenmesi amaçlanmıştır.

Ölçeğin orijinal İngilizce formu, ölçeği geliştiren araştırmacılardan izin alınarak, önce araştırmacı ve 2 uzman çevirmen tarafından Türkçe' ye çevrilmiş, sonra tekrar İngilizce'ye çevrilerek çevirilerin tutarlılı̆̆ incelenmiştir. Çeviriler sonucu elde edilen ölçeğin Türkçe formu, ortaokulda görev yapan 2 Türkçe öğretmeni tarafından incelenerek, öğrencilerin anlayabileceği düzeyde olup olmadığ değerlendirilmiştir. Öğrenciler tarafından anlaşılması zor olan kelimeler belirlenip onların yerine öğrencilerin gelişim düzeylerine uygun anlayabileceği kelimeler kullanılmıştır. Yapılan bu son düzeltmeler sonucu ölçeğin uygulama formu elde edilmiştir.

Araştırmanın çalışma grubunu İstanbul'un Sultangazi ilçesinde yaşayan ve 8. sınıfta okuyan 350 öğrenci oluşturmaktadır. Araştırmaya katılan öğrencilerin yaşları 13 ile 15 yaş arasında değişmektedir. Araştırmada ölçeğin dilsel eşdeğerliği ve test-tekrar test güvenirliği için kullanılan veriler farklı çalışma gruplarına ölçek uygulanarak toplanmıştır. Bu bağlamda, ölçeğin dilsel eşdeğerliği için hem Türkçe hem de İngilizce ölçek maddeleri 34 öğrenciye uygulanmıştır. Test-tekrar test güvenirliği için ise ölçek 4 hafta ara ile 40 öğrenciye uygulanmıştır.

Araştırmada öncelikle ölçeğin dilsel eşdeğerliği incelenmiştir. Bu amaçla ölçeğin İngilizce formu ile Türkçe formu ergenlik dönemindeki bireylere uygulanmıştır. Daha sonra Türkçe ve İngilizce ölçek 
maddeleri arasındaki ilişkiyi incelemek için Pearson Momentler Çarpım korelasyon katsayısı kullanılmıştır. Bu ölçek uyarlama çalışmasında ölçeğin geçerliğini incelemek için yapı geçerliği tekniği kullanılmıştır. Bu bağlamda yapı geçerliğini belirlemek için açımlayıcı faktör analizi yapılmıştır. Kısa Heyecan Arayışı ölçeğinin güvenirliği ise Cronbach Alfa formülü ile hesaplanmıştır. Ölçeğin güvenirliği test-tekrar test tekniği ile de incelenmiştir. Madde analizi için ölçeğin toplam puanlarına göre oluşturulan alt $\% 27$ ve üst $\% 27^{\prime}$ lik grupların madde ortalama puanları arasındaki farklar sınanması amacıyla yapılan ilişkisiz t-testi kullanılmıştır. Ayrıca, madde analizi için ölçek maddelerinden alınan puanlar ile ölçeğin toplam puanı arasındaki ilişkiyi açıklayan madde-toplam puan korelasyonu hesaplanmıştır.

Araştırmada faktör yapısını incelemek için yapılan açımlayıcı faktör analizi sonucu Kısa Heyecan Arayışı Ölçeğinin orijinal yapısına uygun dört maddeli tek faktörlü bir yapıya sahip olduğu bulunmuştur. İç tutarlılık katsayısının .81 olduğu görülmüştür. Madde analizi sonucu, ölçeğin maddelerine ilişkin düzeltilmiş madde-toplam korelasyonlarının 0.56 ile 0.68 olduğu sonucu elde edilmiştir. Ayrıca, madde analizi için yapılan ilişkisiz t-testi sonuçları da $20.24(p<.001$ ile $25.66(p<.001)$ arasında bulunmuştur. Bulgular genel olarak değerlendirildiğinde istatistiksel olarak anlamlı bulgular olduğu söylenebilir.

Çalışma sonucu, geçerlik ve güvenirlik düzeyi yüksek, az sayıda maddeden oluşan, kısa ve kullanışlı bir ölçme aracı Türk kültürüne kazandırılmıştır. Bu araştırma alanyazın açısından ele alındığında, kritik bir gelişim dönemi olan ergenlik dönemi ile ilgili Türkiye'deki yapılan araştırmalarda heyecan arayışı değişkenine de yer verilmesine ve bu çalışmalarda bu faktörün ölçülebilmesine yönelik boşluğun doldurulması için önemli bir adım atılmasını sağlayabilecek niteliktedir. Türkiye'de ergenlik dönemi ve madde bağımlı̆̆ı ile ilgili yapılan araştırmaların sınırlı sayıda olduğu görülmektedir. Bunun en önemli sebeplerinden biri bu durumla ilgili değişkenlerin ölçülmesini sağlayan ölçme araçlarının geliştirilmemiş ya da uyarlanmamıs olmasından kaynaklanmaktadır. Bu araştırma, bu açıdan da düşünüldüğünde alanyazında atılan önemli adımlardan biridir.

Araştırma sonuçları da dikkate alınarak, bu değişkenle ilgili, hem gelecekte yapılabilecek araştırmalara yönelik hem de bu çalışma ile uyarlaması yapılan Kısa Heyecan Arayışı Ölçeğinin ölçme gücünün arttırılabilmesine yönelik bazı önerilerde bulunulabilir. Öncelikle bu araştırmanın çalışma grubunun yaş ve bölge açısından sınırlılıklarının olduğu düşünüldüğünde gelecekteki çalışmaların yaş aralığı daha büyük ve farklı bölgelerde yaşayan bireylerden oluşan daha geniş örneklemlerde yapılabilir. Gelecekteki yapılacak araştırmalarda çalışma grubu seçilirken kültürel geçmişleri, eğitim düzeyleri, yaşanan coğrafik bölge, gibi farklı özelliklere sahip bireylerin katılımı ile oluşturulabilir. Böylece daha fazla hetorejen gruplarda ölçeğin geçerlilik ve güvenirliği de incelenerek ölçme gücü arttırılabilir. Ayrıca gelecekteki yapılacak çalışmalarda heyecan arayışı ile internet, oyun, kumar, alkol, uyuşturucu, sigara bağımlılığı, yıkıcı davranış bozukluğu, hiperaktivite ve dikkat eksikliği değişkenleri arasındaki ilişkilerin araştırıldığı araştırmalar yapılabilir. Bununla birlikte, okullarda görülen istenmeyen öğrenci davranışları, şiddet ve başarısızlık gibi değişkenler ile heyecan arayışı arasındaki ilişkiler de incelenebilir. 
EK-1: Kısa Heyecan Arayışı Ölçeği

Tehlikeli yerleri keşfetmeyi severim

Korkutucu şeyler yapmayı severim

Kuralları çiğnemek zorunda kalsam bile, yeni ve heyecan verici deneyimleri severim.

Ne yapacağı belli olmayan ve macerayı seven arkadaşları tercih ederim. 